"In adopting our title of the fournal of Mental Science, published by authority of the Medico-Psychological Association, we profess that we cultivate in our pages mental science of a particular kind, namely, such mental science as appertains to medical men who are engaged in the treatment of the insane. But it has been objected that the term mental science is inapplicable, and that the term mental physiology or mental pathology, or psychology, or psychiatry (a term much affected by our German brethren), would have been more correct and appropriate; and that, moreover, we do not deal in mental science, which is properly the sphere of the aspiring metaphysical intellect. If mental science is strictly synonymous with metaphysics, these objections are certainly valid; for although we do not eschew metaphysical discussion, the aim of this JourNAL is certainly bent upon more attainable objects than the pursuit of those recondite inquiries which have occupied the most ambitious intellects from the time of Plato to the present, with so much labour and so little result. But while we admit that metaphysics may be called one department of mental science, we maintain that mental physiology and mental pathology are also mental science under a different aspect. While metaphysics may be called speculative mental science, mental physiology and pathology, with their vast range of inquiry into insanity, education, crime, and all things which tend to preserve mental health, or to produce mental disease, are not less questions of mental science in its practical, that is in its sociological point of view. If it were not unjust to high mathematics to compare it in any way with abstruse metaphysics, it would illustrate our meaning to say that our practical mental science would fairly bear the same relation to the mental science of the metaphysicians as applied mathematics bears to the pure science. In both instances the aim of the pure science is the attainment of abstract truth; its utility, however, frequently going no further than to serve as a gymnasium for the intellect. In both instances the mixed science aims at, and, to a certain extent, attains immediate practical results of the greatest utility to the welfare of mankind; we therefore maintain that our JoURNAL is not inaptly called the Fournal of Mental Science, although the science may only attempt to deal with sociological and medical inquiries, relating either to the preservation of the health of the mind or to the amelioration or cure of its diseases; and although not soaring to the height of abstruse metaphysics, we only aim at such metaphysical knowledge as may be available to our purposes, as the mechanician uses the formularies of mathematics. This is our view of the kind of mental science which physieians engaged in the grave responsibility of caring for the mental health of their fellow-men may, in all modesty, pretend to cultivate; and while we cannot doubt that all additions to our certain knowledge in the speculative department of the science will be great gain, the necessities of duty and of danger must ever compel us to pursue that knowledge which is to be obtained in the practical departments of science with the earnestness of real workmen. The captain of a ship would be none the worse for being well acquainted with the higher branches of astronomical science, but it is the practical part of that science as it is applicable to navigation which he is compelled to study."-Sir F. C. Bucknill, M.D., F.R.S. 


\section{BOREATTON PARK.}

Founded by the late W. H. O. Sankey, M.D., F.R.C.P., for the reception of a limited number of ladics and gentlemen mentally afflicted, and now conducted on the same lines by his son, E. H. O. Sankey, M.A., M.B., B.C.Cantab.

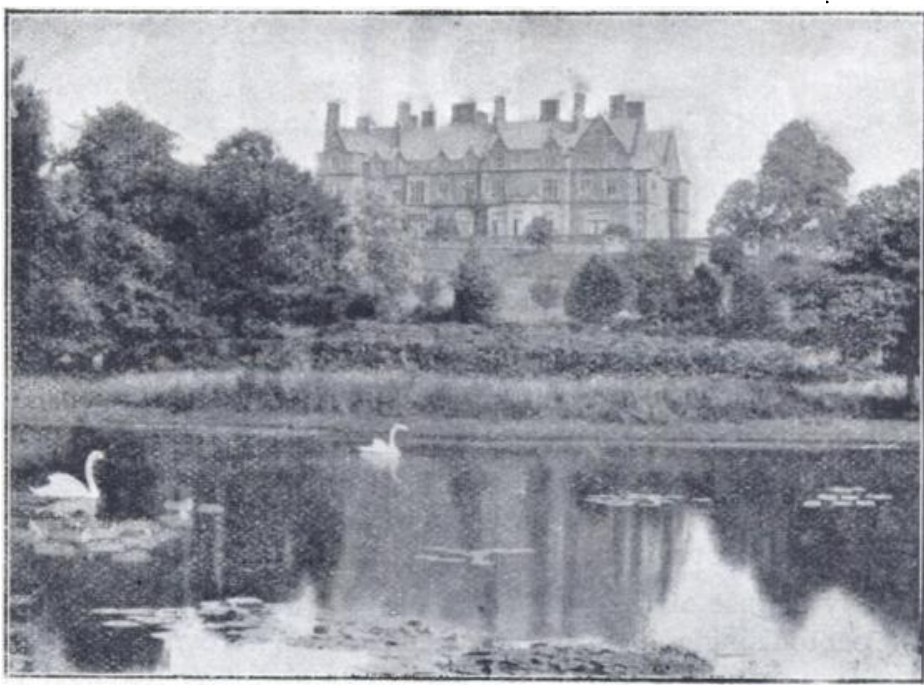

The house, a first-class country Mansion, specially adapted for its purpose, stands about $400 \mathrm{ft}$. above the sea and commands magnificent views of Welsh mountain scenery.

The Gardens slope to the West and lead to the Deer Park, one of the oldest in the kingdom.

There is fishing both for trout and coarse fish in the pools in the Deer Park and the right of fishing in about 5 miles of the River Perry is leased.

There are Hot Houses and Orchard House.

Private Golf Course of 18 holes, Tennis Courts and Croquet Lawns.

So far as possible the patients of both sexes take their meals and associate at all times with the family of the Superintendent, the object being to make the house as much as possible like an ordinary country house.

Arrangements can be made for friends of the Patients to reside in the house should they desire to do so.

There is good stable accommodation, and Horses, Carriages and Motor are provided.

For further particulars apply-

Dr. SANKEY, Boreatton Park, Baschurch, Salop. 


\section{Mental or Physical Fatigue}

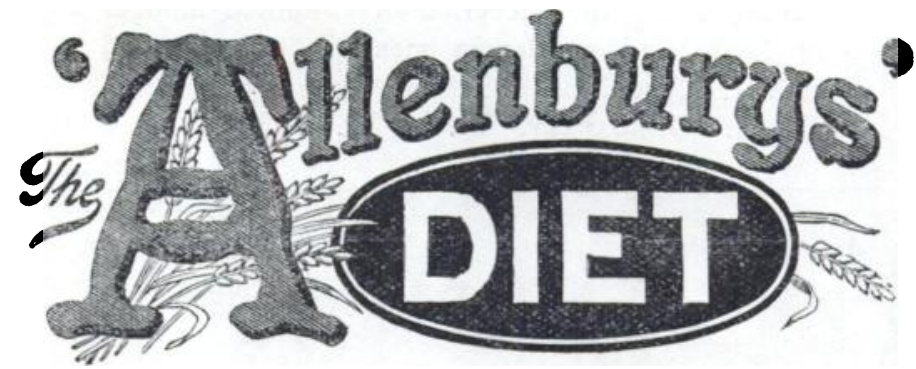

\section{A PARTIALLY PRE-DIGESTED MILK AND WHEATEN FOOD.}

When brain or body is weary the digestive powers are weakened and distaste for ordinary food is often experienced. Under such circumstances the "ALLENBURYS" DIET is especially valuable. It is pleasant to take, easily digested and assimilated, and speedily restorative. Thus it helps the system to recover tone and vigour.

By the use of the "ALLENBURYS" DIET all trouble of peptonising milk and farinaceous foods is overcome. In the sick room it will be found extremely useful as the food is easily digested and assimilated, is quickly made, and only the exact quantity required need be prepared at a time.

The "ALLENBURYS" DIET is made from pure, rich milk and whole wheat, both ingredients being partially predigested during manufacture. It can be taken by those who cannot digest cow's milk, and provides a light and very nourishing diet for Invalids, Dyspeptics and the Aged.

For travellers by sea or land this complete food will be found exceedingly valuable.

Made in a minute. Add boiling water only.

A Sample with full particulars sent free on request.

\section{ALLEN \& HANBURYS Ltd.,}

37 Lombard Street, London, E.C. 
JOURNAL OF MENTAL SCIENCE, OCTOBER, I9I4. ii

\section{SOUTH BEACON, \\ HADLOW DOWN, BUXTED, SUSSEX. ESTABLISHED 1892. \\ Telegrams: “Hadlow Down." Stations: Buxted, Mayfield or Heathfield.}

40 Acres of

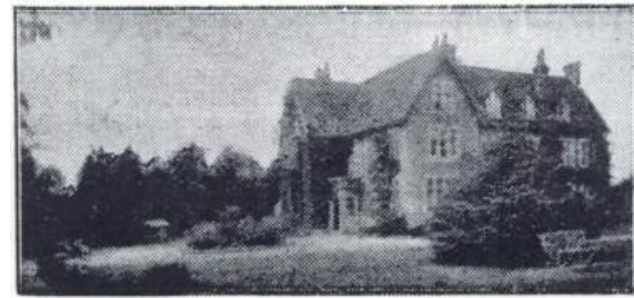

Drixing,

Hotoring;

Golf

Recreation

Ground.

Riding,

and all

Outdoor

recreations.

For the Treatment of Nervous or slight Mental Breakdown.

TERMS FROM 3 GUINEAS PER WEEK.
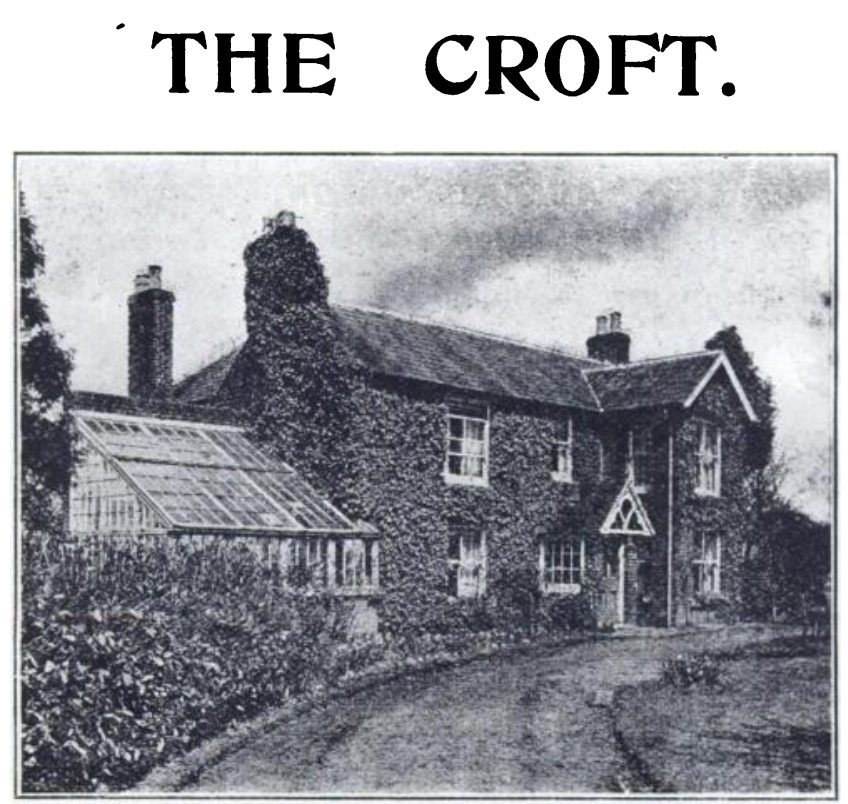

A comfortable cottage residence, where one gentleman can have special care and attention without necessarily coming into contact with other patients.

If desirable he can enjoy all the recreations provided at South Beacon-Motoring, Riding, Golf. 


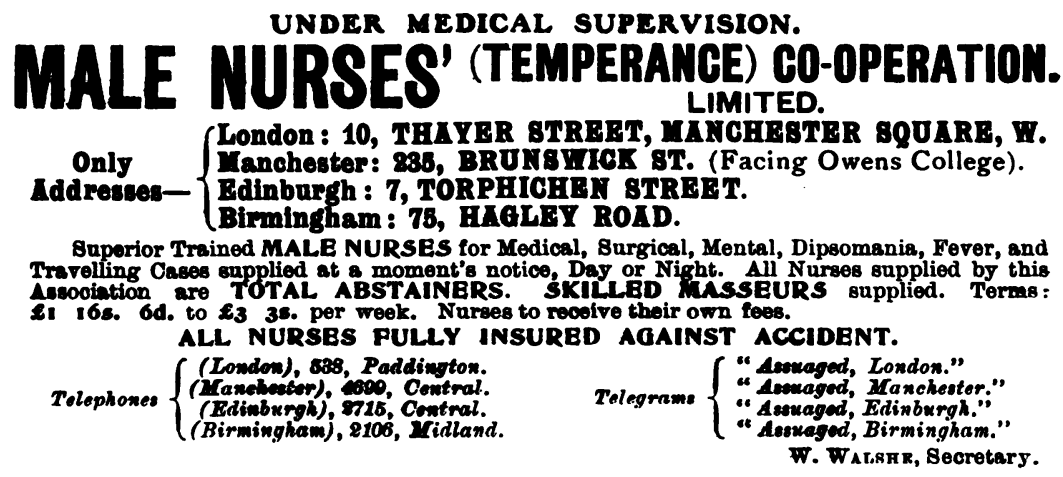

\section{NOTIGE TO ADVERTISERS.}

All Oommunioations conoorning Advertisomonts in "The Journal of Montal Solonoe" should bo addressed to

Mosers. ADLART \& SON,

Bantholomew Olose, London, E.O.

Telephone: Holborn 927.

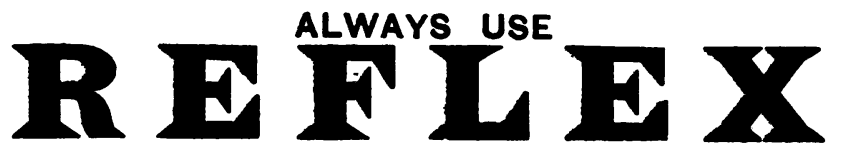

FLOOR POLISH. REQUIRES NO MIXING WHATEVER.

Brilliantly Polishes Floors, Linoleums, Floorcloths, \&c. Fconomical, Cloanly, Healthful; Maximum of Lnstre for Minimum of Labour.

GEO. T. COX \& SONS, Ltd.,

9 \& 10, ST. MARY-AT-HILL, EASTCHEAP, LONDON, E.C.

This Polish is specially adapted for use in Public Institutions and other large establishments. Samples Free on application. 


\section{JOURNAL OF MENTAL SCIENCE.}

Asylum Reports have been received for $1913-14$ from those marked with an asterisk :-Countr,-Beds, Berks, Bucks," Cambridge, Carmarthen," Chester, Chester (Parkside), Cornwall, Cumberland,* Denbigh, Derby, Devon, Dorset,* Durham, Essex, Glamorgan,* Gloucester, Hants," Isle of Wight, Hereford, Hertford, Kent (Barming), ${ }^{*}$ (Chartham)," Lancashire (Lancaster), (Rainhill), (Prestwich)," (Whittingham), Leicester, Lincoln (Kesteven), (Bracebridge), London (Colney Hatch), (Hanwell), (Banstead), (Canehill), (Claybury), (Bexley), (Stone, Dartford)," Middlesex. Monmouth,* Norfolk, Northampton, Northumberland," Nottingham, Oxford, Salop,* Somerset (Wells), (Taunton), Stafford (Stafford)," (Burntwood)," (Cheddleton),* Suffolk,* Surrey (Brookwood),* (Netherne),* Sussex (East), (Chichester), Warwick, Wilts,* Worcester (Barnsley Hall),* Yorkshire (Wakefield)," (Wadsley), (Menston), (Clifton), (Beverley); Borough.-Birmingham (Winson Green), "(Rubery Hill), Bristol, Canterbury, Cardiff,* Derby,* Exeter, Hull, Hayward's Heath,* Ipswich, Leicester, ${ }^{*}$ Middlesbrough,* Newcastle, Norwich, Nottingham, Plymouth, Portsmouth, Sunderland, ${ }^{*}$ West Ham.* Hospitals.-Manchester, Wonford, Barnwood,* Albert, Lincoln,* St. Luke's, St. Andrew's, St. Ann's, ${ }^{*}$ Coppice, Warneford," Coton Hill, Bethlem," Earlswood," Bootham, ${ }^{*}$ Retreat,* Colchester,* Broadmoor, Isle of Man; Metropolitan Asylums Board (Caterham),* (Darenth),* (Leavesden),* (Tooting Bec),* (Rochester House); Aberdeen (Kingseat), ${ }^{*}$ Argyll, Ayr,* Dumfries,* Edinburgh,* Midlothian, Fife, Dundee, Montrose, Inverness,* Lanark, Barony, Glasgow, (Royal)," (Woodilee),* Govan,* Gartloch,* Kirklands, Perth,* Murthly, Roxburgh,* 'Stirling,* Baldovan, Armagh, Ballinasloe, Belfast, Carlow, Castlebar, Clonmel, Cork, Downpatrick, ${ }^{*}$ Ennis, Enniscorthy, Farnham, Kilkenny, Killarney, Letterkenny, Limerick, Londonderry, Maryborough, Monaghan, Mullingar, Omagh, Palmerston, Richmond St. Patrick's, Sligo, Waterford.

The following Asylum Reports have also come to hand:-Egypt, Cape of Good Hope, Nova Scotia, New Brunswick, Victoria, New York, Massachusetts Hospital, Ontario, Verdun, Warren, Pennsylvania, Philadelphia Friends, Binghampton, Willard, Northampton, Long View, South Australia, $\quad \begin{aligned} & \text { Cleveland, Matteawan, New South Wales, Agra } \\ & \text { delphia }\end{aligned}$ and Oudh, Assam, Madras, Bengal, Bombay, Central Pro. and
vinces, Rangoon, Punjab, North-Western Provinces, Tezpur, Mississippi, Pennsylvania Hospital, Washington, Utica, Long Island, Virginia Central, Illinois West, New Hampshire, Butler, Maryland, Pennsylvania West, South Mountain, Manhattan, Indiana East, Connecticut, Carolina N., Dakota N., Ohio, Carthage, Buffalo, Michigan East, Missouri, Alt Scherbitz, Massachusetts Board, Virginia West, Pennsylvania, Danville, Sheppard and Pratt Hospital, Baltimore, Pennsylvania, Harrisburgs, Pennsylvania, Norristown, Aarhus, Lebanon," Hudson River, Rochester, Taunton, Iowa, Jamaica, Grahamstown, Pretoria, Egypt, Albany, Tarrytown, Straits Settlements, Lower Austria.

Authors of Original Papers receive 25 reprints of their articles free of cost if application be made on the slips when returning proof. If any extra reprints are required, notice should be at the same time sent to the Printers, Messrs. ADLARD and Son, Bartholomew Close, London, E.C., who will supply them at a fixed charge. Unless instructions are sent by authors of Papers when the proofs are returned, no copies can be guaranteed.

The copies of the Journal of Mental Science are regularly sent by carrier, who in every case obtains a receipt of delivery, to the Ordinary and Honorary Members of the Association. Complaints of non-receipt of the Journal should be sent to Messrs. ADLARD. Any change of address should be intimated to the General Secretary. 